\title{
The Solution to the Problem of the KGB Reserve and/or National Security Interests
}

\begin{abstract}
Although the KGB in Lithuania officially stopped existing on 1 October 1991, the assessment of the secret service legacy of the communist regime is constantly being revisited. Public researchers point out those aspects of the past that in one way or another continue into the present from peoples past recollections. They also explore those moments that are related to the unaddressed past problems, such as wrongs, a sense of guilt and responsibility, which end up persisting the longest. The article aims at surveying the attitude of the KGB legacy, the relationship to society and politicians, and to one more recent aspect of the KGB legacy that has lately emerged - the so-called "KGB reserve." With respect to the past legacy and memory, with the prevalence of unconstructive standpoints based on partial amnesia and relativism in political circles of the country, attempts to choose more effective action strategies concerning officials who got into the "KGB reserve" scandal and the heads of institutions responsible for national security of Lithuania. These are all analyzed. Reconsideration of the relationship to the KGB has been turned towards parliamentary research and improvement of legal acts. And though from the legal point of view no traces of any "conscious" cooperation have been detected in the publicized past of high state officials or KGB reservists, a considerable part of society does not justify the fact that the past of one or another person was connected with the activity of the KGB, an organization of repressions and terror.
\end{abstract}

\section{Introduction}

Post-totalitarian societies face a difficult task - to coordinate the memory of different groups so that both the victims of the regime and the former organizers and executioners can live without tension in society and build upon a common future. With the restoration of the independence, the Republic of Lithuania has more than once appraised the Soviet State Security Committee (further-KGB) as a repressive institution of the occupation power (Decisions of 4 March 1999 and 10 February 2000 of the Constitutional Court). Therefore, a person belonging to the $\mathrm{KGB}$, or any other secret or private contact (or collaboration) with the KGB can be appraised negatively by society as a circumstance demeaning the honour and dignity of the person. Concealing from society the data known to high political-

\footnotetext{
* Doc. dr. Aroydas Anušauskas is a Director of the Department of the Lithuanian Genocide and Resistance Research Center and Associate Professor of the History Department of the University of Vilnius. Address: Didžioji 17/1, LT-01128 Vilnius, Lithuania, tel. +370 5 2791036, email: arvydas@genocid.lt
} 
power officials about the leaders of the Seimas, the Ministry of Foreign Affairs (further - MFA) and the State Security Department (further - SSD) (or other institutions), who perform important functions in guaranteeing national security, belonging to the "KGB reserve" and or making this data public, could pose a threat to national security.

This only confirms that after symbolic actions such as the-condemning of various aspects of the Soviet past in rallies and the mass media, pulling down of monuments, changing of street names, reestablishment of symbols and institutions that were forbidden in Soviet times, rehabilitation of the repressed, etc. a consistent evaluation of the Soviet security legacy has to also follow. It is true that under conditions of radical breakdowns, social institutions and practices possess quite a few of continual aspects. Mentality and behavioural models, formed in the light of relations with the KGB (or the Lithuanian Communist Party), cannot be changed abruptly or gotten rid of. But all of this must be evaluated not only by reconsidering the past, but also by developing appropriate strategies for dealing with the KGB legacy.

Limitation of the responsibility problem to the activity of only one institution - the KGB - is hardly likely to completely solve the issue of responsibility for the wrong doings of the Soviet time. It should be considered more thoroughly. Assumption of a collective responsibility by members of a group or institution is considered a constructive strategy since it helps perceive and critically evaluate the villainous acts committed by the group, with no personal participation, and prevent them from reoccurrence (restitution in collective responsibility is mostly symbolic and moral, that is things such as an apology, identification of names and so on). Openness and "telling the truth" would not cause enmity in society. On the contrary, this would help reach the necessary agreement faster. But the "KGB reservists" problem (scandal) demonstrated that it is much more difficult to follow this path. The article addresses the objective to review the attitude of the KGB legacy, the relation of society and politicians to one of the KGB legacy has emerged - the so-called "KGB reserve". With these heads of institutions responsible for the national security of Lithuania, having gotten into the "KGB reserve" scandal, the chosen action strategies are being analyzed.

\section{The KGB "Legacy" and Concept of the "KGB Reserve"}

\subsection{The KGB Legacy Assessment Problem}

In many former socialist states, information from secret services archives would leak out and get into the press. At the beginning of 1990, for the first time in Lithuania, attempts were made to play the KGB card by accusing several Sajū dis activists of cooperation with Soviet security in an anonymous letter to the editorial office of the Respublika. After the restoration of independence of 
Lithuania, on 23 March 1990, the Government passed the decision which obligated the KGB to cut short its activity. The essential difference from other Eastern European states lays in the fact that the Soviet Security Institution was outlawed, that is, it became an institution of a foreign state in the Republic of Lithuania. On 27 March 1990, the Supreme Council of Lithuania declared that the agents who "refused to maintain further relations with the KGB of the USSR will experience neither moral nor legal nor any other persecutions by the power of the Republic."1 But the KGB agency network, though considerably depleted (the number of agents decreased from 6,377 to 5,598 as of 1 January 1991) and having almost lost the possibility of renewal (in 1989, in Lithuania, the KGB recruited 358 individuals, in 1990-117 new agents, in $1991-33)^{2}$ still remained a weighty problem of home policy. The KGB legacy kept affecting the society of Lithuania to a rather large extent. Through the USSR Special Services Agency network alone aproximatly 100,000 inhabitants of Lithuania passed, about 50,000 of which were between the years 1956-1990. ${ }^{3}$ The number of people associated with the KGB through other ties - as reliable persons (supplied the necessary help to the KGB due to the positions they held) or as representatives of the communist nomenclature in power (created favourable conditions for the activity of the KGB and used the power of the KGB to retain and strengthen their authority) - was not small either. In 1990-1991, the entire activity of the KGB ranging from the collection of secret information, indirect support for handy politicians and organizations, attempts at slandering and dividing consistent partisans of the independence of Lithuania, to dissemination of information unfavourable for Lithuania in international organizations and Western countries - was directed towards preventing, at first, the restoration of the Lithuanian State and later its international recognition. But on the other hand, KGB possibilities were considerably restricted due to the loss of most opportunities to collect information (disconnection of phone taps, loss of legal access to data bases of the Ministry of Internal Affairs, loss of possibilities to function through former front organizations and control relations with citizens of other countries, and also loss of punitive leverage). Only after 24 August 1991, did it become possible to radically solve the KGB problem. A special commission for taking over the KGB assets and carrying out investigations on their activity was set up. ${ }^{4}$ The KGB institution had to be liquidated within two months.

${ }^{1}$ The Declaration of 27 March 1990 of the Supreme Soviet of the Republic of Lithuania; Collection of Documents I of the Supreme Soviet of the Republic of Lithuania and the Presidium of the Supreme Soviet, Vilnius, 1991, p. 346.

2 Endriukaitis A. "The Cobweb", Lietuvos aidas, 16 January 1992 (in Lithuanian).

${ }^{3}$ According to KGB specialists, influence agents made up 5-10\% within the agency. One fifth $(15-20 \%)$ were the so-called agents "correspondents", i. e., those searching for confirming information, making the facts received more accurate according to KGB tasks. One tenth of all agents were keepewrs of secret and meeting places. The rest were agents-observers, i. e., those recording hostile activity. The KGB wasted the most time on them but the benefit they brought was most often short-lived. See: Денисов С. «Конкретизировать функции каждого агента», Сборник КГБ СССР 53, Москва, 1990, p. 68-69; Леган И., Андреев В. «Какой быть класификации негласных помощников», Сборник КГБ СССР 55, p. 64

${ }^{4}$ Šabajevaite L. Social Transformation of Lithuania in 1990-1997, Vilnius: Vilnius University Publishing House, 1999, p. 32. 
The beginning of the take-over of KGB archives and the adoption of the first special Law "On Verification of the Mandate of the Deputies Suspected of Conscious Cooperation with Special Services of Other States" by scandals of document disappearance and controversially estimated "The Cobweb" articles. ${ }^{6}$ According to Jurgis Jurgelis, then a member of the Commission for the Investigation of the KGB Activity, "because of unjust and inaccurate publications in the press, the procurator's office finds itself in an awkward situation; yet, the Commission never once denied the untruth. Publishing of information and names was not regulated by law, discussed in the Commission and or coordinated with the Prosecutor General's Office. Therefore, innocent people were also compromised." ${ }^{\prime 7}$ Several deputies of the Supreme Soviet were accused of collaboration with the KGB (Virgilijus Čepaitis, Kazimiera Prunskienė, Jokūbas Minkevičius, Vladimiras Beriozovas and others). The Court recognized some of them as former secret KGB collaborators or they themselves renounced the mandates of the Supreme Soviet deputies. By the new election, the mandate of the Supreme Soviet deputy had been taken away from Čepaitis alone. Article 97 of the Election Law, passed by the Seimas on 9 July 1992, provided for the obligation of candidates for members of the Seimas to publicly announce their conscious collaboration with special services of other states. ${ }^{8}$ The KGB legacy issue referred only to former secret collaborators. Possibilities of former and regular KGB officers to get employment in institutions important for national security were not restricted. But with strategies of amnesia (that is "no need to look back into the past", etc.) and relativism (allegedly "everyone collaborated", etc.) becoming prevalent in relation to the Soviet past, in 1993-1997, no other legal steps were taken. No institution for managing, saving and investigating the KGB legacy was established or could even operate for a long time. Fearing for the security of the KGB archives and seeking to prevent their transfer, former political prisoners and deportees were on the watch in the KGB palace in 1993-1996.

\footnotetext{
${ }^{5}$ Document Collection 1 of the Supreme Soviet of the Republic of Lithuania, $p .346$.

${ }^{6}$ Endriukaitis A. The agent "Astra" No. 35348" operated in Marijamplè Sajūdis, Lietuvos aidas, 8 January 1992; Endriukaitis A. "Operational combat platoon in Šakiai and Vilkaviškis", ibid., 4 February 1992; Endriukaitis A."People of Pakruojis zealously executed instructions", ibid, 12 August 1992; Endriukaitis A. "KGB agents in Jurbarkas continue to work", Lietuvos aidas, 8 October 1992; Endriukaitis A."An agent for a special period", ibid, 9 November 1991; Endriukaitis A. "A personal record of an agent", ibid, 23 November 1991; Endriukaitis A. "Reliable persons (about filling in of recruitment documents)", ibid., 29 November 1991; Endriukaitis A. "Against the Church", ibid, 30 November 1991; Endriukaitis A. "The Cobweb", ibid, 4, 14, 20, 29 February 1992; Endriukaitis A. "The Cobweb", ibid, 19 March 1992; Varanauskas P., "A KGB agent planned to overthrow Vytautas Landsbergis by force", ibid, 26 September 1992; Varanauskas P., "'Ketas' spies on the Jesuit", ibid, 22 September 1992; Varanauskas P., "'Džanatas' in the encirclement of KGB sociologists", ibid., 26 August 1992; Varanauskas P., "'Dana' - an internationalist", ibid, 2 July 1992; Varanauskas P., "'Ket' and 'Antanaitis'", ibid, 5 June 1992; Endriukaitis A., "Karalius", ibid, 24 April 1992 and so on

7 Šabajevaitè, (note 4), p. 34

${ }^{8}$ Ibid., p. 36.
} 
In 1996, when the right-wing political forces won the elections to the Seimas, the solution of the lustration problem of KGB collaborators was reverted to again. In 1998-1999, a certain lustration system of KGB agents and regular personnel was set up. Its effectiveness and consequences (negative or positive) for Lithuania are controversial. The former Chairman of the Seimas National Security Committee Algirdas Katkus stated that the initial variant of the Lustration Law was much stricter and more radical, yet it was met with great resistance and many suggestions for improvement: "essentially it was such a law that would "pass" at the time it was adopted". ${ }^{.}$A small group of KGB reserve officers was left aside programming a return to the unsolved KGB legacy assessment problems in the future. In 1999, lustration affected about 300 KGB regular personnel (then working in strategic enterprises, important state institutions, education system). In 1999, there was the adoption of the Law on Recording, Confession, Registration and Security for those who had Confessed to Secret Collaboration with Special Services of the Former USSR. The law defined the categories of individuals having secretly collaborated with special services of the former USSR, determined the order of their confessions as well as established restrictions for persons who had secretly collaborated with secret services of the former USSR but had not confessed to having collaborated with them in the order set by law; many former KGB agents came to confess. Mečys Laurinkus, the former Head of the SSD, claimed that the Lustration Law had solved very many problems; after it came into force, about 1,500 people expressed their trust in the Lithuanian State and admitted having collaborated with the KGB." ${ }^{10}$

\subsection{The KGB Reserve}

For what and how was the KGB creating officer reserve in Lithuania? To make the ideological grounding of the KGB activity clearer, I will quote only a small part of the KGB mobilization work regulations: "One of the most important tasks of the USSR KGB, which defends the Soviet state and society from subversive activities of enemy special services, foreign anti-Soviet centres and adverse home elements, is early readiness to solve the set tasks at the period of threat or wartime." "The period of threat or wartime" was briefly named as a "special period". The KGB had to be ready for urgent actions during the special period and under extreme peacetime conditions, when need for thoroughly preselected, pre-tested, at least minimally trained and most importantly, reliable new personnel for carrying out additional functions could arise.

Officers of the armed forces of the Soviet Union were transferred to the KGB reserve on the grounds of the aforementioned mobilization and readiness plans for the "special period". In selecting reservists for operational work in

\footnotetext{
${ }^{9}$ Kuzmickaite J. "For those who confessed - sanctions, for those that kept silent - open ways", Atgimimas 2, 2005.

${ }^{10}$ ELTA, M.Laurinkus: Materials of Soviet special services cannot be relied upon 100 per cent,19 February 2005.
} 
KGB institutions, priority was given to those working in party-political institutions, having legal education, work experience in industrial and transport enterprises, belonging to the organizations of the Communist Party and the Komsomol, and those meeting requirements for service in the KGB. The philosopher Vytautas Radžvilas claimed that persons, having chosen in Soviet times one or another method of collaboration with the KGB, had already identified themselves to the Soviet Union. "I believe that all those people had one feature in common - they truly did not believe that Lithuania could gain independence, stated the philosopher. Being a reserve officer was partly a condition conducive to the accumulation of political capital; they could expect a fast career advancement." ${ }^{11}$ According to the journalist Valdas Vasiliauskas:

However, even here the nomenclature had privileges. While enjoying career advancement, a reservist would also make "career" in the military registration: he was usually transferred to the category of political leaders. A person particularly reliable and loyal to the system was assigned to the KGB reserve. This meant rather another nomenclature privilege than collaboration with the KGB, and was particularly secret. ${ }^{12}$

In fact, it is possible to partly estimate being in the "KGB reserve" as both another privilege of the former nomenclature and a possibility to gain a faster position in the nomenclature. Careerism was one of the more distinct features of a part of reservists. On the other hand, a lot of people who had never belonged to the nomenclature were included in the KGB reserve. But their loyalty to the communist system and suitability to the KGB activity were undoubtedly verified. Those selected to the KGB reserve were of most the diverse civil specialties - teachers, engineers, lawyers, heads of enterprises or establishments, employees of communist party organizational institutions, etc. This does not confirm the speculations, expressed during the "reservists" scandal, that "it is dominated by the elite of Soviet society."13 At the beginning of February 2005, after TV3 television aired names of high officials who at some time had been included in the KGB reserve ${ }^{14}$, the list held scarcely 70 names.

Agreement to be in the KGB reserve was given orally. According to the USSR KGB mobilization work regulations:

According to the wartime table of organization, selection of the USSR armed forces reservists to man KGB bodies is conducted by carrying out initial selection according to the KGB-MIA (Ministry of Internal Affairs) registrations. Candidates, designated for officer positions, are summoned to Military Commissariats with the aim of getting biographical data for a complete special verification and there they obtain an agreement from them to serve in the KGB institutions in wartime [...], for all other positions - without summons. Mobilization officials, employees of regular apparatuses, operatives of KGB bodies carry out the selection of reservists. [...] After the special verification is finished and suitability to work for the KGB is established, the selected

${ }^{11}$ Makaraitytè I. "Estimation is but moral", Atgimimas 4, 2005.

${ }^{12}$ Vasiliauskas V. "Retaliation: the plan 'The KGB Reserve'”, Lietuvos rytas, 17 January 2005.

${ }^{13}$ Ibid.

${ }^{14}$ Barkauskaite O. "An investigation into who leaked information about KGB reservists will be conducted", www.delfi.lt, 17 February 2005. 
are summoned to Military Commissariats for interviews during which their agreement to serve in the KGB in wartime is ascertained. The reservists have given their agreement in complete fixed-format questionnaires. ${ }^{15}$

A comprehensive special verification of the selected officers was carried out. Personnel of the KGB territorial subunits and special KGB divisions would collect characteristics about candidates for the KGB reserve and would always arrange meetings with them (if necessary, they met more than once). They would also look into personal qualities during interviews. Military Commissariats were obligated not to interfere with KGB representatives in carrying out selection of reserve officers for KGB purposes.

The compilation and management of personal records of KGB reserve officers was conducted on the grounds of an Annex to the KGB of the USSR Soviet of Ministers order No. 0330 of 20 June 1978 - "Instruction about the Selection and Verification of Candidates for Regular Military Service and Work at the State Security Committee of the USSR Soviet of Ministers." 16 Provisions of the same Law were also applied in selecting candidates for work in staff positions (regular personnel) and forming the contingent of KGB reserve officers. According to Chapter 7 of the Selection and Verification Instruction of 20 June 1978 by the KGB of the USSR:

Personnel of operational subunits to whom this was assigned, must personally investigate the candidates, use operational forces and measures to this end, and also conduct such a form of their investigation as verification by assignments of operational character [...] with the aim of determining suitability of the candidate for agentialoperational work in the central apparatus of the KGB. In KGB bodies, they (except persons that are directly transferred from party, Soviet or Komsomol work) are requested by an employee of a respective subunit to help (if necessary conditions for that exist) with carrying out concrete assignments of operational character."17 Having received information that candidates are not suitable for service or work in KGB bodies and the military, the KGB would refuse to further work with them. ${ }^{18}$

According to the mobilization readiness report of 1988 of the KGB in the Lithuanian SSR, to man the KGB in compliance with a wartime ("special situation") table of organization, they needed 903 people: 624 officers and 279 enlis-

\footnotetext{
15 USSR regulations for mobilization work (project of 1989), Special Archive of Lithuania (further-SAL), stk. K-1, inv. 46, f. 2833, p. 217, 261. Completed forms of those who gave their agreement to be included into the KGB reserve are stored in their personal records in the present SAL.

${ }^{16}$ The Instruction about the selection and verification of candidates for regular military service and work at the State Security Committee of the USSR Soviet of Ministers, Centre for the Documentation of the Consequences of Totalitarianism (Republic of Latvia).

${ }_{17}$ The Instruction, (note 16), Chapter 7. Personal records of KGB reserve officers contain hints of giving and execution of operational assignments. See: SAL, stk. K-1, inv. 52, f. 187; f. 82, p. 19-22; f. 176 , p. $21-22$; inv. 46 , f. 2789 , p. 35-1, 35-2. Subunits of the Soviet Union that operated in Latvia, Estonia and Lithuania followed uniform instructions and laws, but KGB archives in these countries survived with a different structure. In Latvia mostly laws and instructions that regulated the KGB activity survived, whereas in Lithuania more documents of operational activity and personal records remained.

${ }^{18}$ The Instruction, (note 16), Chapter 11.
} 
ted personnel. Officers were categorized as KGB reserve officers, 72 and 552 reserve officers of the armed forces. ${ }^{19}$ This was the number of new personnel that was needed to replace regular KGB personnel who had to be transferred elsewhere, to take KGB staff officer positions for the execution of additional functions - to command operational-combat elements in each district, to carry out preventive arrest plans of "unreliable persons" and so on. KGB reserve officer actions depended more on combat readiness degrees that territorial KGB institutions were assigned. For example having received the signal, territorial KGB institutions, supplemented by reserve officers, had to carry out "special operational measures" to detain persons who in wartime conditions would pose a particular threat to the state. On 29 September 1989, Eduardas Eismuntas, the LSSR KGB Chairman proposed to include in the list of persons to be detained "leaders and activists of anti-socialist informal organizations who speak for the change of the existing state system, can organize and implement extremist actions including those of a coercive, group nature." ${ }^{20}$ But because of different assigned functions, not all reserve officers of the armed forces were transferred to the category of KGB reserve officers. All KGB reserve officers had to become KGB operatives. Besides, it was the plan to assign a part of them as operatives of special divisions of military units of the USSR KGB special divisions for the Baltic Military District (in 1985, 185 KGB reserve officers were to be assigned for that purpose) ${ }^{21}$ who had to spy on the mobilized, explore their disposition and spy on politically unreliable people. It was these needs that the formation of the KGB reserve officer reserve was orientated towards. On 1 January 1989, the KGB reserve held 357 officers, 232 from which were transferred from the armed forces reserve (others were former KGB staff personnel). ${ }^{22}$ On 27 December, in Lithuania, 420 reserve officers of the USSR KGB were registered ( 273 of them were transferred from the armed forces reserve), while on 25 March 1991 there were 370 KGB reserve officers. ${ }^{23}$ Even in 1990-1991, after a part of those transferred to the KGB reserve refused to stay in the KGB "reserve", the number of reservists (excluding former regular KGB officers) amounted to more than 200.

In 1989, with changes in the political situation in Lithuania, the first refusals to stay in the KGB reserve were registered in KGB documents. ${ }^{24}$ Why didn't the KGB reserve disappear after the restoration of independence of Lithuania? According to the opinion of the professor Albinas Bagdonas from Vilnius University Faculty of Philosophy, even though self-identification with the idea of statehood did not disappear in one instance -

During the last decade of the regime [Soviet - A. A.], conformism and collaboration with the regime was seldom motivated on the ideological grounds. [...] That decade-long oppression fostered the "learned helplessness" behaviour described by American psychologists. [...] Such behaviour is usually followed by duplicity of cons-

${ }^{20}$ Ibid., f. 2833, p. 261.

${ }^{21}$ Extract No. M/0531 of 4 July 1985, ibid., f. 2711, p. 31-4.

${ }_{22}$ The mobilization readiness report of the KGB of the Lithuanian SSR, ibid., f. 2833, p. 7.

${ }^{23}$ Report on work in 1990 (27 December 1990), ibid., f. 2767, p. 10-11.

${ }^{24}$ Report of the Chief of Telšiai district KGB division to the Chief of the mobilization division of the LSSR KGB, ibid, inv. 45, f. 2845, p. 74 rev. 
cience [...] Double-dealing of those in power was also clearly perceived. Ideological pomposity had little to do with everyday practice..$^{25}$

Regarding a part of those in power in present-day Lithuania and who were included in the KGB reserve 16-25 years ago, it is possible to discern a certain psychological motivation determined by the "learned helplessness" (that is "what could I do", "I was only one out of many", "others also behaved likewise" or in some other way motivating their choice). In 1990, due to political motives, some officers included in the KGB reserve would refuse to accept military cards of KGB reserve officers and consequently would be excluded from the KGB reserve for the special period. After such refusals, on 28 September 1990, the LSSR KGB Chairman, Maj. Gen. Romualdas Marcinkus issued the order to all chiefs of town and district KGB divisions: "seeking for reliability of KGB reserve officers and armed forces reservists, designated for KGB institutions", additional verification of this contingent (that is of those belonging to Units No. 300/1400 and 300/1400B) is planned. For example, in Klaipeda, out of 30 interrogated officers 8 refused to stay in the KGB reserve, out of 30 enlisted personnel 8 also refused. ${ }^{26}$ In Kaunas, 34 persons were interrogated and, due to political reasons, $5 \mathrm{KGB}$ reserve officers refused $^{27}$, etc. Sometimes reserve officers were interviewed individually ${ }^{28}$ or appraised according to their activity and the position they held (belonging to Sajūdis, leaving the ranks of the CPL, working in power institutions of the Republic of Lithuania $^{29}$ ). Ignalina, Anykščiai, Varèna, Kupiškis, Pasvalys, Prienai, Salčininkai, Švenčionys, Širvintos and some other KGB divisions did not find any unreliable persons. In the report of 25 March 1991, 38 persons who refused to stay in the KGB reserve in 1990 are mentioned whereas in January-March of 1991, one more person refused to stay in the reserve and 43 were excluded from the lists due to motives that hindered their employment in the service. ${ }^{30}$ But at that time, membership in communist organizations was no more among the selection criteria and "during the special period" it was planned to use, in conjunction with military units, under "special situations," 1616 KGB reserve officers in the positions of operatives ${ }^{32}$ (not including several dozen of them who planned for work

\footnotetext{
25 "The Conformists", Atgimimas 3, 2005.

${ }^{26}$ A note of 4 December 1990 by the Chief of Klaipeda city and the Lithuanian Sea Basin KGB division, SAL, stk K-1, inv. 46, f. 2727 p.84-86.

${ }^{27}$ A letter of November 1990 by the Chief of Kaunas city KGB division to the Chief of the LSSR KGB mobilization division, ibid, p. 88.

${ }^{28}$ A note of 12 November 1990 by the Chief of Varena district KGB division, ibid., p. 63 rev.; A letter of November 1990 by the Chief of Kaunas city KGB division to the Chief of the LSSR KGB mobilization division, ibid, p. 88.

${ }^{29}$ A note of 5 November 1990 by the Chief of Silalès district KGB division, ibid., p. 80-80 rev.; A note of 4 December 1990 by the Chief of Klaipeda city and the Lithuanian Sea Basin KGB division, ibid., p. 83 rev. -86 .

${ }^{30}$ Report on work in 1990 (27 December 1990), ibid., f. 2767, p. 10.

${ }^{31}$ On 8 December 1989, the KGB Chairman E. Eismuntas requested the Chief of the USSR KGB mobilization division Maj. Gen. A. B. Suplatov to make an agreement with military units deployed in Lithuania to cover main KGB subunits during "special situations":Vilnius and Kaunas KGB divisions were to be covered by the airborne division of the 7th Guards, Klaipeda KGB - by the 23rd border platoon, Panevėžys KGB - by the units of the 18th military-transport Guards division.

32 SAL, stk. K-1, inv. 46, f. 2727, p. 57.
} 
in territorial KGB divisions). In 1990, reserve officer personal records began to be sent out of Lithuania; primarily records of those reserve officers who were 50 years of age and were excluded from the reserve. Thus, on 10 January 1990, 33 personal records were sent to the Omsk KGB archive. On 21 February 1990, "in connection with the complicated operational situation in Lithuania" 141 records of KGB reserve officers were sent to Omsk. Among them were records of the former regular KGB officers, mostly those of majors and officers with higher military ranks, which were the first to be transferred to the reserve. The rest of the records remained and are now stored in the Special Archive of Lithuania (stk. No. K-1, inv. No.52).

But during the "reservists" scandal, the former SSD Director Laurinkus stated that "no records of the Soviet time should be believed 100 percent." According to Laurinkus, the issue of the KGB reserve was already discussed in preparing the Lustration Law. By that time, the SSD had already supplied information on the status and role of the KGB reserve during the Soviet time to the working group that was preparing the Law. "The KGB reserve institution, I am deeply convinced, was a purely bureaucratic paper institution which itself I do not think realized what its role was, particularly during the future war", explained the former Head of the SSD. It is possible to agree that the KGB reserve was rather a formal institution, but had selection to it and there was verification of reliability, along with the extraction of the agreement to collaborate with the KGB and repeated selection and reliability verification procedures of the KGB staff individuals. Though belonging to the KGB reserve in society could be estimated negatively as a circumstance demeaning the honour of the person, "reserve" investigation did not go beyond the "presentation of information". Five years after the "presentation of information", society learned from the data published in the mass media (the weekly "Atgimimas", the daily "Lietuvos žinios"), that the member of the Seimas Alfredas Pekeliūnas in 1985 was included in the mobilization documents of the territorial KGB subunit - Panevėžys city KGB division and designated for operational work in the erritorial KGB subunit. In December 1989 Arvydas Pocius was included into the lists of the KGB special division for the Baltic Military District and designated as an operative of the special division of the military unit deployed in Vilnius. In 1981, Antanas Valionis was included into the lists of the KGB special division for the Baltic Military District and was designated as an operative of the special division of the military unit deployed in Sovietsk (Kaliningrad region). Lack of publicity in appointing persons with undisclosed and publicly un-assessed hardly representative biographical data to authoritative positions in institutions responsible for national security turned the solution of the KGB reserve problem into a scandal. 


\section{KGB "Reserve" Problem in 2004-2005}

\subsection{Genesis of the Scandal}

In 2004, the political career of several high foreign state officials was ruined because of direct or indirect connections with Soviet security. For example, the Sejm of Poland discharged Josef Oleksy from the Chairman position of the Lower House of Parliament. The Court established that Oleksy collaborated with secret services of communist Poland but concealed this fact. In Lithuania, a similar problem with high state officials got ripe in November of 2004 (for the second time after 1991-1992).

The Chairman of the Seimas Artūras Paulauskas was supplied with material by representatives of the oppositional Homeland Union which stated that in September of 1990, Pekeliūnas was included in the lists of KGB units 300/1400 B made up of reserve officers and soldiers. The Chairman of the Seimas Paulauskas addressed the State Security Department asking to check whether or not his deputy Pekeliūnas had concealed his connections with the State Security Committee of the Soviet Union - the KGB. ${ }^{33}$ Pekeliūnas claimed he had never collaborated with the KGB and heard about his inclusion in the reserve list for the first time. ${ }^{34}$ "This is the job of right-wing politicians. They seem to possess the archives and have found a piece of paper with my name on it" $^{\prime \prime 35}$, said Pekeliūnas. But the escalation of the "right hand" did not justify itself since the "reservist" scandal kept expanding and ever new actors were included in it. It was necessary to foresee new strategies regarding the relation with the legacy and memory of the past.

At that time, strategies for further actions were only being formed and attempts were being made to either use official institutional ways (by requesting the SSD to verify the received information) or apply laws still in force and define the possibilities of persons that "consciously collaborated with the KGB." The Chairman of the Chief Election Commission Zenonas Vaigauskas stated that, in case it turned out that Pekeliunas had actually concealed his collaboration with the Soviet KGB, he would face his mandate being taken away through impeachment. ${ }^{36}$ According to commentators, "it is very likely that because politicians set themselves an objective to defend people from the 'KGB ghosts'. They may also urge them to 'let bygones be bygones' or it could possibly be due to other reasons such as the fact that persons who are holding much more important positions among the KGB reserve officers have been concealed." ${ }^{37}$ In response to Paulauskas' inquiry, the State Security Department (SSD) replied that "the SSD had no data about Pekeliūnas' collaboration with the KGB." The statement that "birds

\footnotetext{
${ }^{33}$ BNS, A. Paulauskas addressed the SSD in reference to A. Pekeliūnas' connections with the KGB, 30 November 2004.

34 Ibid.

35 Ibid.

36 Ibid.

${ }^{37}$ Makaraitytė I. “The KGB „Reservists“ Screen Pulled Away, Atgimimas, No. 1.
} 
of a feather cover each other"38 by the then leader of the Homeland Union, a member of the European Parliament Vytautas Landsbergis provoked further attention concerning this problem.

When the information published in the weekly "Atgimimas" made it clear that the Director General of the State Security Department Pocius and the Minister of Foreign Affairs Valionis were included in KGB reserve lists, proposals to apply a "fat-line" strategy between the past and the present were by far most popular. "Instead of racking our brains about how to use the EU support billions more effectively, we burrow ourselves in old KGB records" ${ }^{\prime 39}$ stated Vasiliauskas, a journalist of the influential daily "Lietuvos rytas". But, according to the journalist Indre Makaraityte, officials were appointed to high positions "by consciously concealing biographical particulars that were far from representative." 40

\subsection{Choice of Action Stratagems}

In relation to repressions and repressive institutions (KGB) of the past, in the memory and behaviour of societies, such strategies most often arise: collective amnesia, when more embarrassing moments are "forgotten" and in public memory speaking about them is avoided (specifically, this also manifests itself as the position of a "fat line" between the past and the present); the transfer of guilt to individual people groups and demonizing of these groups (for example, "bourgeoisie", "communists", "Nazis"); relativism of responsibility and suffering ("everyone suffered", "everyone was a collaborator, etc.); victimization, when a group or society that suffered are perceived as a victim; along with discussion and continual reconsideration of the memory, named by Jurgen Habermus as "memory work" ${ }^{41}$ Memory reconsideration strategy (it can also be called publicity and lustration strategy), in seeking societal harmony, is the most productive if this discussion is public, open, honest and experiences as well as memories of all societal groups are heard in it. The reconsideration of the "reservists" problem that happened at the turn of 2004-2005 can partly be called this, but the question arises as to whether it was done honestly and openly. Amnesia and relativism strategies identified by specialists are particularly unconstructive, postponing solution of problems important for people and "societal harmony", and thus hindering concentration on the present ${ }^{42}$ and they begin to manifest themselves in much more refined forms than previously (first of all by laws limiting the possibility to explore, assess and publicize KGB documents to non-governmental institutions or pre-assessing such activity as political struggle or a possible tool of political struggle).

${ }^{38}$ Gorienè G. "A. Paulauskas will take possession of Lithuania by using the Russian "mass employment psychic weapon", Laisvasis laikraštis, January 2005.

${ }^{39}$ Vasiliauskas, (note 12)

${ }^{40}$ Makaraityte, (note 39)

${ }^{41}$ Šutinienè I. "The Post-Soviet Dilemma“, www.delfi.lt, 27 January 2005.

${ }^{42}$ Ibid. 
Proponents of the reconsideration of memory and relation to the past strategies (identified as the most productive) were accused of having caused total confusion, political chaos, destructive passions which would stir up society, along with undermining its solidarity and mutual trust. "Here a political game of a much higher level was started" 43 , stated commentators of the daily "Lietuvos rytas". Having evaluated the presence in the KGB reserve as only an additional privilege of the nomenclature but not as an additional possibility to seek careers among the communist regime nomenclature which was then the verification of loyalty to the system, was the objective of the sprung up scandal and was considered as the result of the antithesis between the right-left-wingers as a political struggle. "The right-wingers intended to strike a blow to both other graduates of the party educational institutions and entire nomenclature who had returned to power with the Labour party ${ }^{44}$, and destroy the ruling coalition." In the KGB reservist scandal a multitude of interests coincided: "the rightwingers wanted to stop the nomenclature, the paksists - to take revenge on Paulauskas. ${ }^{\prime 45}$ On the other hand, the publicity of the KGB reserve data was also assessed as an action of an internal and invisible, to the broad public, political struggle in order to, by some extent, weaken the political power of the Chairman of the Seimas taking over from him the Prosecutor General's Office and the State Security Department. ${ }^{46}$

Sometime before the Lustration Commission made the decision about the character of the "KGB reserve officer" and collaboration with the KGB, the minister Valionis claimed to "Atgimimas" that he did not want to make any comments because he had received an answer from a responsible Lithuanian institution that such activity is not considered as "secret" collaboration with the KGB. ${ }^{47}$ An agreement given in secret to be included in the KGB reserve, participation in reserve trainings held by the KGB, beyond doubt indicated an agreement to collaborate when appropriate situations occurred. But as mentioned, the SSD did not realistically investigate the genesis of the reserve emergence and associate the presence of secret (and private) information about KGB reserve officers in the archives of Russian secret services with possible threats to national security. Meanwhile, the Chief of the SSD Pocius stated to "Atgimimas" that he did not know anything about his inclusion in the KGB officer reserve and only during the period of Lithuania's independence realized that the KGB had started his personal record. [...]

"Between 1993-1994 I learned about the existence of some KGB documents and that they could be used against me." ${ }^{\prime 48}$ Those that found themselves under the scrutiny assessed their situation as either conscious provocation still prepared by the KGB or as a problem discussed by only highest-level politicians yet insignificant.

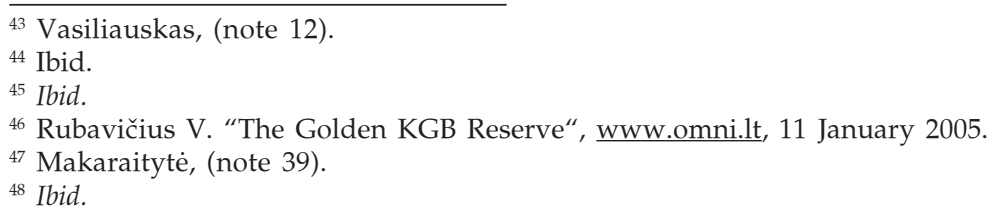


The fact that a negative attitude of society to relations with the KGB had an impact on the work of MFA and SSD authorities and could indirectly pose a threat to national security, destabilize the political situation or atmosphere within institutions responsible for national security was made more apparent by commentaries in the mass media about the situation in the SSD. According to the commentators, Pocius lost control of the situation in the Security Department and not all subordinates are loyal to the present Head. After the information about the former relations with the KGB of the Director General of the SSD, Pocius was published in the political weekly "Atgimimas". Copies of the personal record held at the Special Archive were passed by other means to the mass media by "mysterious and helpful hands". "Lietuvos žinios" prepared several exhaustive publications from the materials included in the personal record. But the internal friction at the SSD was but only one consequence of the fight that started much earlier for influence over the authorities of the SSD. Observers of the political process noticed that tension with reference to who can head the State Security Department started building towards the end of the term in office of the former SDD Director Laurinkus. It reached its climax when the then President Rolandas Paksas, who had then been already removed from office, proposed Gintaras Bagdonas, the Head of the $2^{\text {nd }}$ MoD Department, to the post of the SSD Director. In the spring of 2004, when the impeachment came to an end, the acting President Paulauskas appointed Pocius, who was proposed by Laurinkus and had been his former deputy, as the Director General of the SSD. While "Atgimimas" was preparing material about the connections of Pocius and politicians with the KGB, some interviewed persons feared that publishing this information would be useful for individuals fighting for influence in the SSD. That competition within the SSD, manifesting itself in leaking information, concealing problems or publicizing them when it was useful for a faction competing for influence, could pose a threat to state security. ${ }^{49}$

Since the "reservists" scandal was expanding and included heads of institutions responsible for the national security of Lithuania, it was necessary to foresee new, more effective action strategies. The emerged KGB reserve scandal showed "a special quality of our ruling elite, certain attributes of the state of society and new unending actions of political struggle".$^{50}$ In other words, connections with the former communist nomenclature and direct or indirect ties with the KGB that defended its interests indicated both the state of some ruling elite and possibilities to influence it. Shortly, attitudes of political party leaders with reference to "reservists" started shaping, meanwhile providing for possible further actions. Proposals were made for officials to retire, appeal to the Lustration Commission, publicize names of all reservists, and or set up a parliamentary investigation.

\footnotetext{
49 "A Look", Atgimimas 4, 2005.

${ }^{50}$ Rubavičius, (note 46).
} 


\subsection{Reconsideration of the Memory - Lustration and Publicity Strategy}

Following the publicity strategy, assessment of the "reservist's status" had to be attributed to the Commission evaluating the activity of persons that secretly collaborated with special services of the former USSR. Representatives from the SSD, the Genocide and Resistance Research Centre of Lithuania and the Prosecutor's Office were delegated to this interdepartmental Commission. As early as the beginning of the KGB reservist's scandal, when the Prime Minister Algirdas Brazauskas requested the Lustration Commission to assess the relations of Valionis and Pocius to the KGB, the Chairman of the Commission (representative of the SSD) Vytautas Damulis mentioned that the Lustration Commission had no legal basis to look into the activity of KGB reservists. According to him, the Lustration Commission had been authorized to look into the activity of only those that collaborated with the KGB, whereas being in the reserve, according to laws in force then, was not regarded as conscious collaboration with this organization. ${ }^{51}$ The Opposition party the Liberal and Centre Union (the LCU) demanded that the assessment should be given by the Lustration Commission. In the opinion of the LCU Chairman, Artūras Zuokas, having taken this measure and having received conclusions of the investigation of the Lustration Commission, high officials could peacefully continue their work, thus avoiding different interpretations of their reliability that might arise in society. ${ }^{52}$

In fact, laws in force in Lithuania define belonging to the KGB reserve in an ambiguous way. According to the Law "On Recording, Confession, Registration and Security of those who Confessed of Secret Collaboration with Special Services of the Former USSR" that came into force in 2000, KGB reservists contrary to regular Soviet security personnel, did not have to appeal to the special Lustration Commission. However, the Law "On the Verification of the Mandates of Deputies Suspected of Conscious Collaboration with Special Services of Other States" that came into force at the end of 1991 stipulated that the concept of "collaboration" comprises inclusion of a person in the lists of KGB (MGB) or other special services or his recruitment or other conscious and consistent (two and more times) activity - provision of information to the KGB or other special services, setting or execution of tasks was not included. A member of the Lustration Commission Birutė Burauskaite stated that reserve officers were not included in the Law possibly due to the circumstance that their ties with the KGB seemed different, having a smaller degree of loyalty to this service. ${ }^{53}$ Yet, though the Lustration Commission intended to self-determine whether belonging to the KGB reserve should be assessed as conscious collaboration with Soviet security,

\footnotetext{
${ }^{51}$ BNS, The Lustration Commission Loses its Head, 8 February 2005.

52 "The Minister of Foreign Affairs and the Chief of State Security Have to Go for a Lustration X-ray“, Lietuvos rytas, 10 January 2005.

${ }^{53}$ Kuzmickaite J. "For Those who Confessed - Sanctions, for Those that Kept Silent - Open Ways", Atgimimas 2, 2005.
} 
the material available was insufficient to make an unambiguous appraisal of the status of the Soviet security reserve ${ }^{54}$. It was impossible that a person included in the reserve would not be aware of it; however, the definition of "conscious collaboration" was in this case essential. Having started to deal with this issue, the Lustration Commission soon became inoperative. Further developments stimulated discussions about the effectiveness of the activities of the Lustration Commission. The Head of the State Security Department (SSD) Pocius was among the first to state that, the Lustration Commission, which had so far been subordinate to the Department, in the future would have to become an independent institution, whereas the Department should render assistance to it. The composition of the Commission had to be renewed and the person to be designated its new chairman had to be well known to society. "The Commission should be completely independent, make independent decisions in assessing the activity of the working group and materials presented by $\mathrm{it}^{\prime \prime 55}$, claimed Pocius. In fact, all members of the Commission delegated by the SSD were, at the same time, members of the working group and could not be fully independent and unbiased. Damulis, the Chief of the Counterintelligence Directorate of the SSD, who was the Head of the Commission, resigned from the position of the chairman of his own free will. Other members of the Commission were also urged to resign.

The Commission, which until then could not boast of the effectiveness of its activity, managed to evade dealing with the issue of the KGB reserve. The Lustration Commission approved its conclusion that individuals included in the KGB reserve were not to be identified as secret collaborators of Soviet security. The Chairman of the Lustration Commission Damulis claimed that this conclusion was not specially meant for any particular institution and was made "after KGB-related documents stored in archives were analyzed, persons who in the past kept records of KGB reservists as well as archivists were interrogated" ${ }^{\prime \prime 6}$. This, however, did not ease the tension.

The parliamentary working group, which was preparing amendments to the laws regarding the assessment of the activity of Soviet special services, suggested that the lustration deadline should be extended. "The working group tends to believe that the confession deadline should be repeated and exten$\operatorname{ded}^{\prime \prime 57}$, said the Chairman of the National Security and Defense Committee (NSDC) Alvydas Sadeckas. Considerations also began as to how to raise the status of the Lustration Commission and change its formation principles while transforming it from departmental to departmental-public". According to Sadeckas, a variant that the highest officials of the state - the President, the Prime Minister and the Chairman of the Seimas - could also delegate members for the Lustration Commission; this was considered.

${ }^{54}$ ELTA, The Lustration Commission will Appraise the Status of the KGB Reserve, 7 February 2005.

${ }^{55}$ ELTA, Aleknaite K. "A.Pocius: The Lustration Commission cannot be Subordinate to the SSD", 21 February 2005.

${ }^{56}$ BNS, KGB Reservists are not Secret KGB Collaborators, 21 February 2005.

${ }^{57}$ BNS, The Lustration Deadline is Suggested to be Extended, 21 February 2005. 
The problem of publicity of KGB archives was closely related to the lustration process. Making KGB archives secret had been an instrument for special services, for the ruling nomenclature to control a part of society making it a hostage in their fight for power and political influence ${ }^{58}$. The Liberal Centrists, the Conservatives, and the Labour Party, all having different interests and goals, supported the idea of publicizing the KGB archives.

"Lists of KGB reserve officers should be publicized to society" ${ }^{59}$ in order to avoid blackmail of foreign states' special services, said Zuokas ${ }^{60}$. To this end, it was suggested to improve legal acts and, first of all, the controversial Law on the Regulations of the Use of Archives restricting access to the archives of Soviet special services for several decades ${ }^{61}$. The Labour Party faction also stood for publicizing the materials of the Special Archive and lists of former KGB collaborators $^{62}$. According to the stance of the Labour Party faction, the Special Archive had to be completely open. Juozas Olekas, one of the leaders of the Social Democrats, said that he supported the opinion that all reservists of Soviet security should be made public "so that no one kept prying" ${ }^{\prime 63}$. At the same time, he said, people who had had an opportunity to browse through KGB records would be prevented from occasionally exposing to the public information on one or another high official or public figure. The SSD Director General Pocius, who found himself in the centre of the scandal, held a similar view. He suggested that the issue of publicizing lists of KGB reservists should be dealt with immediately in order to put an end to the "witch hunt". The Minister of Foreign Affairs did not object to publicizing KGB records kept in the archives, either ${ }^{64}$. Commonality of propositions made by the Liberal Centrists, the Social Democrats and the Labour Party referred to the attempts at seeking publicity in order to protect people from blackmail and stop "speculations" on this issue. A discussion and continual reconsideration of the past, i. e. "memory work", was not suggested.

During the so-called KGB reserve scandal, Andrius Kubilius, the Chair of the Homeland Union faction of the Seimas, put forward a proposal to make the materials of the Special Archive public and publicize lists of former KGB collaborators: "follow the example of the Czechs and Slovaks and put personal records of the Special Archive on the Internet websites". In 2003, the Czechs publicized 75,000 names of former collaborators with secret services on the website of the Ministry of Interior Affairs, and the Slovaks put information with 21,000 names of former collaborators on the Internet ${ }^{65}$. According to Kubilius, the order existing in Lithuania and attempts at making the archives secret for the

${ }^{58}$ Rubavičius, (note 46 ).

${ }^{59}$ The Minister of Foreign Affairs and the Chief of State Security Must Go for a Lustration XRay, Claim Liberal Centrists, Lietuvos rytas, 10 January 2005.

${ }^{60}$ Ibid.

${ }^{61}$ Ibid.

62 "The Labor Party Urge to Publicize KGB Reserve Lists", www.delfi.lt, 11 January 2005.

63 "J. Olekas: If a Radical Decision is Made, A. Pocius Could Live more Peacefully", ibid.

${ }^{64}$ "State Authorities Knew about the Belonging of A. Valionis and A. Pocius to the KGB Reserve", www.delfi.lt, 7 January 2005.

${ }^{65}$ BNS, Andrius Kubilius: The Archives should be Open to Society, 10 January 2005. 
next 70 years could not resolve any problems that we face today, but aggravate them: "we will face the same problem when new facts about collaboration of some officials come out" 66 .

Publicity in this field was "imported" from Poland. On 13 January 2005, the Internet website $\mathrm{ABCnet}$.com.pl propagating right-wing ideas published a document translated into Polish which, as was stated was the order of 26 December 1989 signed by Eismuntas, the then Chairman of the State Security Committee of the Lithuanian SSR, as well as some earlier decrees issued by him concerning the inclusion of Soviet army officers in the KGB reserve. The mentioned list contained 61 individuals, including Pocius, the Director General of the State Security Department of Lithuania ${ }^{67}$. Until then, the list of KGB reservists had never been publicized because it was confidential. Skirmantas Pabedinskas, who headed the Special Commission of the Seimas on the Investigation of Circumstances of the Inclusion of High State Officials in the KGB Reserve, warned that "this will only do harm to society because the list is inaccurate and even obviously forged in some places ${ }^{\prime \prime 6}{ }^{6}$. The mass media of Lithuania published the list. Afterwards, it started getting clear that members not only from the New Union, but also from the Labor, Social Democratic and other parties might have been involved in the vortex of the "reservists" scandal.

\subsection{Parliamentary Investigation and Improvement of Legal Acts}

Suggestions were made that the problem of conscious and "unconscious" collaboration with the KGB as well as the belonging to the KGB reserve should be dealt with by primarily improving legal acts. Thus starting with the Law on Recording, Confession, Registration and Security of those who Confessed to Secret Collaboration with Special Services of the Former USSR, thus the problem of KGB reserve officers be resolved ${ }^{69}$.

Other proposals were connected with adoption of legal acts providing access to all KGB archives, promoting in this way self-establishment of a free civic society. This was emphasized by the oppositional Homeland Union: "to initiate such amendments to the Law on the existing order and Archives which would make the Special Archive completely open" ${ }^{\prime 70}$.

With new political forces being involved in the discussion about the problem of the KGB "reserve", parliamentary investigation eventually became a dominating strategy. When the Liberal Democrats faction of the Seimas came up with the initiation of a parliamentary commission, which would investigate

${ }^{66}$ Gorienè, (note 38).

${ }^{67}$ ELTA, BNS, A. Anušauskas: The List of KGB Reservists on the Internet is Genuine, 16 February 2005.

${ }^{68}$ Verification of the document confirmed its authenticity, it was found in the Special Archive of Lithuania.

${ }^{69}$ Olekas, (note 63).

${ }^{70} \mathrm{BNS}$, (note 65). 
facts about the relations of high officials with KGB institutions ${ }^{71}$, other political parties for some time remained sceptical about the efforts of their opponents in the former Presidential scandal.

The Liberal Centrists were also sceptical about the establishment of a parliamentary commission and suggested that Valionis and Pocius should be invited to be interviewed by Parliament members in the Seimas. The Chair of the Homeland Union faction Kubilius, had urged the aforementioned officials to answer the question themselves if they could further perform their job at a proper level ${ }^{72}$. In the middle of January 2005, it turned out that the ruling majority was going to set up a commission. Parliamentary investigation had to glean information about the ties maintained with Soviet security by the three state officials - the Minister of Foreign Affairs Valionis, the Director General of the State Security Department Pocius and the Vice-Chairman of the Seimas Pekeliūnas $^{73}$. According to the Liberal Democrats, the decision to establish the commission in which "the questions were formulated more correctly" implied that the commission was not going to elucidate whether the officials who were in the KGB reserve did not lie when they claimed that they did not know that. Besides, the issue regarding a moral right of the officials to work for the state after their ties with foreign special services had been revealed was not to be discussed. Also, no interest would be taken in the fact whether state officials were aware that the designated officials had belonged to the KGB reserve ${ }^{74}$. It is likely that both the ruling parties and the opposition did not consider the KGB reserve a serious problem to national security due to the predominant attitudes to draw "a fat line" between the present and the past and judge the individuals that had once got in the reserve by their present merits.

\section{5. "The Fat Line" and Indications of Collective Amnesia}

The historical experience of the $20^{\text {th }}$ century shows that sooner or later society goes back to the unresolved problems of the memory. Even having clearly assessed the criminal past on the public plane, there still remain quite a few hush-ups in people's private lives and their relationships. The "forgotten" or denied personal experience that is important to the individual has a destructive effect on both the personality and, as a frequent phenomenon, society. However, this was not taken into account in applying amnesia and relativism with respect to the Soviet past. An elaborate manifestation of that became the tactics used of "awareness" of KGB reservists chosen by the highest state officials (allegedly important only in position designation).

71 "R. Paksas Claims that Officials' Ties with the KGB were Deliberately Concealed", www.delfi.lt, 11 January 2005.

${ }^{72}$ Mazuronis V. Who and Why Should "Forget" the Past?, www.omni.lt, 10 January 2005.

${ }^{73}$ ELTA, The Lustration Commissions will Appraise the Status of the KGB Reserve, 7 February 2005.

74 "Valentinas Mazuronis: The Alternative Commission is Going to Elucidate the Alternative Truth", www.delfi.lt, 18 January 2005. 
Not having estimated to what extent the publicly unresolved problems related to the assessment of the past, can destructively affect society and the institutions involved in the scandals. Whether or not this can become a serious problem to national security, was why the so-called "fat-line" policy was adopted: the past was separated from the present and the only criterion for assessing officials had to be competence and loyalty to the new government. Before Pocius was approved as the Head of the SSD, on 27 March 2004, in the Seimas, he was asked if he had collaborated with the KGB, either as an agent or as a "doverennoje lico" (Russ. "a reliable person") or in any other way. Pocius answered: "Certainly not. I am not connected with this institution"7 5 . "Back in 1992-1993, I heard rumours that there were certain documents related to me, but I did not respond to that. [...] Later, I asked the authorities to investigate the circumstances, but they assured that that was not a problem" ${ }^{176}$, said the Director of the SSD Pocius.

The Chairman of the Seimas Paulauskas claimed that the facts related to the past of both the Minister and the Director General of the State Security Department (SSD) were being made public for certain purposes, including the political ones. This was in order to, i.e., cast aspersions on these officials, to question their loyalty and increase tension within the ruling coalition. According to the Chairman of the Seimas, the biography of the present Director General of the SSD "was no secret to those officials who either appointed or recommended him nor to those authorities that he had previously worked with"77. The SSD had allegedly known about that before Pocius was invited to work in this institution. Moreover, the fact that Pocius belonged to the KGB reserve had already been publicly announced. The Chairman of the Parliament reminded them that the year before, prior to designating the official the Director General of the SSD, a publication appeared in the press disclosing this fact of his biography. Afterwards, this material was verified and submitted to the then acting President Paulauskas. "We did not consider this an important circumstance in his life ${ }^{\prime \prime 78}$, said the Head of the Parliament. Actually, before the appointment of Pocius as the Director of the SSD, Paulauskas said he had no information that this official had been included in the lists of KGB reserve officers (the temporary Commission, however, was not authorized to investigate the facts of "awareness- unawareness").

Clarity and unconditional publicity, when appointing responsible positions, was eliminated. Information concerning former contacts of responsible officials with the KGB (no matter how they themselves assessed them) had to be publicized before they were nominated for the posts, even though according to Lithuania's laws, being included in the KGB reserve is not considered to be "secret and conscious" collaboration with secret services of the Soviet Union ${ }^{79}$.

${ }^{75}$ Gorienè, (note 38).

${ }^{76}$ Barkauskaite O. "A. Pocius: My Case was Falsified", www.delfi.lt - Lithuanian radio, 17 February 2005.

77 "State Authorities Knew about the Belonging of A. Valionis and A. Pocius to the KGB Reserve", www.delfi.lt, 7 January 2005.

${ }^{78}$ Ibid.

79 "The Minister of Foreign Affairs and the Chief of State Security Must Go for a Lustration XRay, Claim Liberal Centrists", Lietuvos rytas, 10 January 2005. 
Minister Valionis assured that both in 1994, when he was appointed the ambassador in Warsaw, and in 2000, when he was to be appointed minister for the first time, he did not conceal his past ${ }^{80}$. He said that both in 1994, before becoming the ambassador of Lithuania to Poland, and in 2000, before being designated the Minister of Foreign Affairs, he had consulted with others about the issue whether this fact of his biography might raise "certain legal, ethical or other problems. [...] I was told that this was not regarded as collaboration. The authorities of the state knew about that, they had been informed" ${ }^{\prime 1}$, pointed out the head of the Lithuanian diplomacy. He claimed that he had confessed to belonging to the KGB reserve even to President Adamkus.

President Adamkus claimed that he did not know this fact, though later he specified that Valionis was appointed minister several years ago, therefore he could not remember everything well ${ }^{82}$. The impeached President, the Chairman of the Liberal Democratic Party Paksas expressed great surprise that during the time when he held the positions of the Prime Minister and the President of Lithuania, neither the Chairman of the Seimas nor other responsible officials provided information on the ties of Valionis and Pocius with the $\mathrm{KGB}^{83}$. When the investigation in the Seimas started, it turned out that the "awareness-unawareness" problem concerned judges too. Vytautas Greičius, the Chairman of the Supreme Court and the Head of the Courts Council, stated that "in KGB reserve lists, three names of judges were mentioned who were included there in order to avoid constant summons to military trainings" ${ }^{\prime 4}$. Since the parliamentary Commission did not look into these circumstances, there was no precise answer with evidence testifying to "awareness-unawareness".

The former Head of the State Security Department (SSD) and present ambassador of Lithuania to Spain Laurinkus stated that it was strange that at that time "the focus is on the individuals who have demonstrated to Lithuania their very sincere and effective work ${ }^{85}$. [...] It is humiliation to these people and on such a basis which from the point of view of Lithuania's security makes no sense" 86 . Laurinkus claimed that he had been informed about the belonging of both Pocius and Valionis to the KGB reserve and he had informed the then President Adamkus and later - when appointing Pocius as Head of the SSD the acting President Paulauskas about "the inclusion of Pocius in the KGB reserve under vague circumstances" ${ }^{\prime 87}$. As the former Director of the SSD, he once again gave assurance that he had not considered and did not consider that

\footnotetext{
${ }^{80}$ Olekas, (note 63).

${ }^{81}$ Note 82.

${ }^{82}$ Olekas, (note 63)

${ }^{83}$ Note 71.

${ }^{84}$ Among those included in the KGB reservists list were the Deputy Chairman of Kaunas City Circuit Court, a member of the Courts Council Edmundas Inokaitis and the judge of the Criminal Cases Division of Klaipeda District Court Valentinas Janonis. See: ELTA, V. Greičius: Two Judges Asked to be Included in the KGB Reserve, 21 February 2005.

${ }^{85}$ BNS, The Minister of Foreign Affairs and the Head of the SSD by their Work Proved Loyalty to Lithuania, 8 January 2005.

${ }^{86}$ Ibid.
} 
the fact of being in the KGB reserve or possible information about that, when it was possibly in the hands of special services of a foreign state, might cause a threat to national security.

Before the publicizing, the general trend in assessing the KGB reserve was to observe the policy of "the fat line" between the past and the present. It seemed that the past could be forgotten without having been appraised. State authorities and some other influential politicians explained that the inclusion in the KGB reserve was of little significance, it was like some kind of formality dictated by life circumstances, it was not any crime, it did not pose a threat to our state and did not equal to conscious collaboration. Whereas those who had once been bound to the KGB reserve now were people with great merits to Lithuania. According to present laws, these people should not be regarded as violators, although there was no doubt that laws were made with many exceptions, most often choosing compromise variants. Such attitudes could be looked upon as both a clear policy regarding the past (the memory) and expression of collective amnesia.

In sum, both Valionis and Pocius were appointed to the state posts while keeping away or concealing from society and even the Seimas, their former belonging to the KGB officer reserve. Belonging to this reserve was not considered an important matter, therefore, it was thought sufficient that only a few state officials who were in charge of appointing to positions knew about that.

Aspects of "the verified loyalty" were related to the impact of the "reservist's scandal" on the international position of Lithuania. Although Lithuanian laws do not treat the inclusion in the KGB reserve as "secret and conscious" collaboration with secret services of the Soviet Union, according to Valionis, the shadows of collaboration "can be part of a political game attempting to undermine our position in negotiations with Russia". The Chairman of the Seimas Paulauskas declared that so far in relations with Russia, Valionis had "a clear and principled stand" and demonstrated that "interests of Lithuania" were important to him ${ }^{88}$.

It is interesting to note that the daily "Lietuvos rytas" that had never been known for Russophobia and the "paranoia" of total spying, assessed "the reservist's scandal" as "the most successful operation of the decade in Lithuania" ${ }^{89}$ or manipulation of public opinion performed by Russian special services ${ }^{90}$. It is obvious that special services of Russia were and are trying to penetrate into the most important state institutions, armed forces, parties, institutions related to NATO and the European Union, while intensifying their activity and increasing their capabilities in Lithuania ${ }^{9}$. After the role that Lithuania had taken during the orange revolution, the strengthening of Russia's positions in Lithuania was predicted. According to the French daily "Le Figaro", "it might be im-

\footnotetext{
87 Ibid.

${ }^{88}$ Ibid.

${ }^{89}$ Vasiliauskas, (note 12).

${ }^{90}$ Vainauskienè B. "KGB Ghosts Refuse to Go on Holiday", Lietuvos rytas, 10 January 2005.

${ }^{91}$ Jakilaitis E., "Covert Tentacles of Moscow won't Let Lithuania Go", Lietuvos rytas, 13 January 2005
} 
portant to Russia to raise discord with Lithuania, the relations with which have always been tense" ${ }^{\prime \prime 2}$. The Director General of the State Security Department, Pocius, declared that "there are certain directions in the activities of special services following which efforts are made to devalue the membership of Lithuania in the EU and NATO. Attempts are also made to make our country become an insignificant member of international organizations ${ }^{\prime \prime 93}$. However, there were no facts to confirm the unequivocal answer that Russian special services do not play second fiddle. Quite the contrary, Russian special services, still employing some KGB methods and having the KGB legacy at their disposal, did not comment on the ongoing scandal and, most likely, used the opportunities offered by the possession of the remaining part of the KGB archives and the internal political scandal which then was at its climax in Lithuania.

\section{The Temporary Investigation Commission and its Conclusions}

\subsection{Establishment of the Commission and Formulation of its Objectives}

By decision No. X-98 of 20 January 2005 of the Seimas of the Republic of Lithuania (Žin., 2005, No. 12-365), a temporary Commission was set up to investigate the facts and circumstances regarding the inclusion of the Deputy Chairman of the Seimas Pekeliūnas, the Director General of the State Security Department Pocius and the Minister of Foreign Affairs Valionis in the lists of the State Security Committee of the USSR. Skirmantas Pabedinskas, a member of the Labor Party, was appointed its chairman. The Commission was obligated to appraise the status of KGB reserve officers, establish under what circumstances the three aforementioned officials that were included in the lists of Soviet security reserve, as well as determine whether legal acts were not violated by appointing them to their current positions, and whether their being in present positions did not pose a threat to national security interests, and whether other present day politicians, judges or state officials were included in the lists of the KGB reser$\mathrm{ve}^{94}$. Besides, the Commission had to establish if being in the KGB reserve could

${ }_{92}$ ELTA, "Le Figaro": the Past Keeps Hold on Lithuanian Politicians", 20 January 2005.

93 "The SSD Points out to Greater Attention of Special Services of Certain States to Lithuanian Affairs", Lietuvos rytas - BNS, 13 January 2005.

${ }^{94}$ BNS, The Seimas Approved the Composition of the Temporary Commission on the Investigation of the Relations of Officials with the KGB, 21 January 2005. The objectives of the temporary Commission were formulated: What is the status of the KGB reserve and individuals included in the lists of the KGB reserve: what functions the KGB reserve performed, in what way individuals were included in these lists, what impact this inclusion had and has on their positions Under what circumstances were Alfredas Pekeliūnas, Arvydas Pocius and Antanas Valionis included in the lists of the KGB reserve? Are there any other state politicians, judges or persons holding the positions of state officials included in KGB reserve lists? 
be equalled to conscious collaboration, which is assessed more seriously, providing for restrictions in holding positions in state service. The Deputy Chairman of the Commission Rimantas Dagys pointed out that in some cases the activity of KGB reservists could pose a threat, but "each case must be investigated as a concrete one ${ }^{\prime \prime 9}$. Had the Seimas temporary Commission on the investigation of the KGB reserve stated that the agreement to be included in the KGB reserve was equal to conscious collaboration with the Soviet special service, this would cause "very serious consequences". Had the temporary parliamentary Commission confirmed the fact of conscious collaboration, the members of the Seimas who were in the KGB reserve would be under a threat of losing their mandates. However, according to a member of the Chief Election Commission (further-CEC), the fact of conscious collaboration should further be confirmed by the Lustration Commission or court. Had the Lustration Commission or court recognized the fact of conscious collaboration, the CEC would have to acknowledge that while filling in the form of as a candidate for the member of the Seimas, they concealed this fact. When standing for the Seimas, the Deputy Chairman of the Seimas Pekeliūnas and the Minister of Foreign Affairs Valionis did not indicate their conscious collaboration with special services of other states carrying out tasks assigned not by the state of Lithuania ${ }^{96}$.

However, since the Lustration Commission did not consider the belonging to the KGB reserve as conscious collaboration, the Chief Election Commission analyzed a letter of application written by Saulius Pečeliūnas, a member of the Homeland Union faction ${ }^{97}$ concerning the application of the Law of 1991. Pečeliūnas suggested that the "Law on the Verification of Mandates of the Deputies Suspected of Conscious Collaboration with Special Services of other States" that came into force at the end of 1991 should be used as a basis. In this law, the notion of "collaboration" was specified as inclusion of an individual in the lists of the KGB (MGB) or other special services; or recruiting a person as a resident, agent, authorized agent, confidential agent or informer as well as evidence of corresponding activity; other conscious and systematic (two and more times) activity, such as provision of information to the KGB or other special services, task assignment or execution, etc. ${ }^{98}$ The CEC declared that it could not establish the fact whether or not during the Soviet period these parliamentarians collaborated with the KGB or other special services for it was within the competence of court. Members of the CEC claimed that they did not and could not have documents which, following the order established by law, would confirm the juridical fact that Valionis and Pekeliunnas collaborated with special institutions of other states. "The State Security Department was inquired and

\footnotetext{
95 "The Lustration Commission is Going to Reassess the Belonging to the KGB Reserve", www.delfi.lt, 4 February 2005.

${ }^{96}$ BNS, Members of the Parliament who of their own Will Got into the KGB Reserve Can Lose their Mandates, 3 February 2005.

${ }_{97}$ BNS, A. Valionis and A. Pekeliunnas did not Violate the Law on the Election to the Seimas, 3 February 2005.

${ }^{98}$ Ibid.
} 
did not confirm the fact of collaboration; consequently the candidates had been registered legitimately. However, if even now the fact was confirmed, the law would not give the right to the CEC to take their mandates away", said Victoras Rinkevičius, a member of the Commission. "To pronounce that someone belonged to the reserve is not to pronounce conscious collaboration" ${ }^{\prime \prime 9}$, stated the members of the CEC.

Records of the KGB reserve were compiled in accordance with instructions given then according to which personal contacts of KGB officers, with a potential KGB reserve officer aiming at extracting an agreement to belong to this reserve and confirming reliability, were of the utmost importance. In their explanations provided to the temporary investigation Commission of the Seimas, the Minister of Foreign Affairs Valionis and the Director of the State Security Department Pocius confessed to their belonging to the KGB reserve in the Soviet period. As Valionis said, "the LSSR KGB gave me an already completed form [...] and informed me that I had already been included in the KGB reserve of reserve officers. [...] I could not see possibilities to protest against such a decision because nobody had asked me to give an agreement to be transferred to the KGB reserve of reserve officers" ${ }^{\prime 100}$ [from reserve officers of the armed forces of the USSR - A. A.].

In his evidence given to the temporary parliamentary Commission investigating the connections of high officials with the KGB, while answering addition questions, the Head of the State Security Department (SSD) Pocius stated that "there are lots of discrepancies, and my record was plotted behind my back. [...] The only document testifying to my agreement was the impression someone else had that I agreed"101. According to Pocius, he got acquainted with his record before he started working in the SSD ${ }^{102}$.

First of all, the members of the Commission expected to get the official list of all KGB reservists. The list was requested from the SSD, the interdepartmental Lustration Commission and the Genocide and Resistance Research Centre of Lithuania (further-GRRCL). Had it turned out that the reserve list contained more officials holding high positions, then they according to the Chairman of the Commission Pabedinskas, would be made public. It was expected that we would find out if those included in KGB reserve lists had given their written agreement to be included, if they made commitments to carry out tasks of the Soviet security department, and what for incentives were given. The members of the Commission expected to discover if these individuals had to keep information about their belonging to the reserve secret, if there were those who refused to be included in the reserve, if after the restoration of Lithuania's independence they continued their activities and whose instructions they followed: were they given by the officials who lived and worked in Lithuania or these instructions

\footnotetext{
99 Ibid.

${ }^{100}$ DELFI-BNS-ELTA, A. Valionis and A. Pocius Confessed the Belonging to the KGB Reserve, 7

February 2005.

${ }^{101}$ Barkauskaitė O., (note 76).

${ }^{102}$ Ibid.
} 
used to come from Moscow. The Commission requested each institution to state their opinion on what kind of security mechanism should be set up for the individuals included in the reserve lists. At that time, the law did not obligate KGB reservists to appeal to the special Lustration Commission. The latter was required to provide a report on how the Law on Lustration, that came into force in 2000, was so far being enforced ${ }^{103}$.

The obtained answers raised doubts to the members of the temporary investigation Commission of the Seimas concerning the impartiality of historians of the country and a suggestion was made to request the estimation of the activity of the KGB reserve from Russia [i.e. in fact, from the Federal Security Service that had the rest of the KGB archives at its disposal - A.A.]. The Liberal Centrist Raimundas Šukys, the originator of this initiative, stated that this was a way to use every possible source of information. "Representatives of the Genocide and Resistance Research Center of Lithuania (GSRCL) hold a categorical opinion", said Šukys providing motives for his suggestion. After the voiced criticism that "the request that Moscow estimate the activity of the KGB reserve would undermine the authority of Lithuania's institutions and primarily, that of the Seimas", this proposition was rejected. Finally, it was decided to leave it to the Ministry of Foreign Affairs itself to answer which states should be requested to provide information on the activities of the KGB reserve ${ }^{104}$. The Commission decided to request information from the Head of the Department of Operational Activity of Mykolas Riomeris University Kestutis Šimkus (the adviser to President Adamkus on the issues of organized crime and corruption prevention $)^{105}$. No official requests for additional information were made even from the closest neighbour Latvia, whose archives still have, most probably, the most comprehensive base of normative acts which regulated the KGB activity.

\subsection{Conclusions of the Commission: the KGB Reserve "Equals to" Compulsory Military Service}

In its meetings held in the period from 28 January to 28 February 2005, the Commission established that in the analysis of the issue of the KGB reserve and the status of individuals included in KGB reserve lists, attention should be paid to the fact that laws and other legal acts of the Republic of Lithuania define neither the status of the KGB reserve nor individuals included in KGB reserve lists. The inclusion in the KGB reserve had no impact on work or official activity because there were no commitments, pledges, etc. [though nothing was said as to how to appraise the agreement to be in the KGB reserve-A. A.]. The necessity for corresponding positions would arise only in the case of the outbreak of war. Being in the KGB reserve should be compared to doing compulsory military service (this conclusion was made on the basis of the 11 February 2005 letter

${ }^{103}$ Gudavičius S., New Names in the KGB Vortex “, Kauno diena, 29 January 2005.

104 "An Unofficial KGB Reserve List Wandering in the Seimas", www.delfi.lt, 29 January 2005.

105 Autoriaus faile nèra išnašao teksto 
written to the Commission by assoc. Prof. Šimkus). However, no explanation was given as to why a person who avoided compulsory military service would be brought under penal code, whereas no sanctions were imposed for the one who refused to be KGB reserve officers. On the other hand, no estimation was given to the fact that service (or work) in KGB institutions was equalled to the service in the armed forces.

\section{The Commission concluded that:}

The USSR KGB reserve was a mobilization part of the KGB designed for cases of the special period (threat of war, beginning of war, natural disasters and mass riots) and war. [...] The Commission has no accurate data available as to whether the inclusion in KGB reserve lists had an impact on the positions held by the persons included (though no comments are given on whether this helped make a career in the then communist nomenclature - A. A.). People who agreed to be included in the KGB reserve had various motives - career possibilities, avoidance of military service. According to the data of the Commission, refusal to be registered in the KGB reserve did not cause any consequences ${ }^{106}$.

Based on the available data, the Commission drew a conclusion that Pocius was included in the list of KGB reserve officers, but the Commission did not possess sufficient data to conclude whether he knew that. The Commission decided that Valionis was included in the KGB reserve, which he was later informed about. Trying to determine if the order of appointing to posts provided for in legal acts was not violated when the individuals who had been included in KGB reserve lists were appointed to their current positions, the Commission established that the fact of inclusion in the lists of the State Security Department (KGB), i. e. a special service reserve, was not sufficient to claim that the person actually collaborated with special services. Besides, apart from the objective indication of secret collaboration with special services - actual execution of tasks and assignments - a subjective attribute was necessary, i. e. while carrying out tasks and assignments, the person must act consciously according to a written or verbal commitment. Thus, a person who performed assignments given by special services had to be consciously aware of whose tasks and assignments he was executing. Taking this into consideration, the Commission made a conclusion that when Valionis was designated Minister of Foreign Affairs and Pocius was designated Director General of the State Security Department, the requirements provided for in legal acts of the Republic of Lithuania were not violated.

The Commission had no data to confirm that Valionis, Pocius or Pekeliūnas carried out any tasks or assignments or in any other way committed themselves to fulfil them in the future. According to the Commission, this presupposes the fact that none of the aforementioned persons had to admit their inclusion in the KGB reserve lists.

\footnotetext{
106 "Conclusions of the temporary Commission on the investigation of the facts and circumstances related to the inclusion in the lists of the State Security Department Reserve of the USSR of the Deputy Chairman of the Seimas of the Republic of Lithuania Alfredas Pekeliūnas, the General Director of the State Security Department of the Republic of Lithuania Arvydas Pocius and the Minister of Foreign Affairs of the Republic of Lithuania Antanas Valionis", 1 March 2005, http://www3.lrs.lt/.
} 

of the Commission concerned the application of the Law of the Republic of Lithuania "On the Verification of Mandates of Deputies Suspected of Conscious Collaboration with Special Services of Other States". The Commission decided that, regarding the circumstances and content of its passage, it could not in fact be any longer applied. According to the Commission:

Norms [but not all - A.A.] analogous to the provisions of the aforementioned law are provided for in the special Law passed in 1999. The law on "Recording, Confession, Registration and Security of those who Confessed to Secret Collaboration with Special Services of the Former USSR". The aforementioned law is applied not only to members of the Seimas but also to other state officials, state employees and persons employed in state establishments and institutions. Therefore, with the emergence of the fact about secret collaboration of the members of the Seimas with secret services of the former USSR, the law does not comply that with, the formed current social relations governed by law, that it should be applied ${ }^{107}$.

Taking this into account, the Commission concluded that the responsibility for not informing the state of Lithuania about the fact of secret collaboration with secret services of the former USSR, which is provided for by law can be applied neither to Valionis nor Pocius nor Pekeliūnas.

According to the Law on the Fundamentals of National Security, one of the key objectives of national security is human and civic rights, freedom and person's security. It also comprises a person's security when freedom of action is restricted while threatening to publicize data compromising him. According to the Law on the Fundamentals of National Security, the authorities of the state are bound to secure Lithuania from subversive activity of secret services of foreign states. This activity can be characterized by the application of conventional and unconventional methods and new technologies in order to illegally obtain information, destructively affect and influence military capabilities, political processes and other areas of social and economic life. The Commission decided that due to the fact that the Seimas, the Ministry of Foreign Affairs, and the State Security Department carry out particularly important functions in guaranteeing national security, illegal restriction of freedom of action of heads of these institutions threatening to publicize data compromising them might have an impact on the activity of these institutions. Therefore, considering the importance of the functions performed by these institutions, in this way, it is a threat to national security could be posed.

After the restoration of independence to the Republic of Lithuania, in Lithuanian legal acts, the KGB has more than once been evaluated as a repressive institution of the occupational power. Thus, belonging to the KGB reserve could be unfavourably estimated in society and considered to be a circumstance demeaning a person's honour and dignity. For this reason, and based on the aforementioned facts, threatening to publicize the data about the heads of the Seimas, the Ministry of Foreign Affairs and the State Security Department belonging to the KGB reserve could illegally restrict their freedom of action and thus,

${ }^{107}$ Ibid. 
alongside the activity of foreign special services, could pose a threat to national security. On the other hand, after the Commission established that Pocius and Valionis belonged to the KGB reserve, these data became public [though they became public not due to the Commission - A. A.]. That is why there was no possibility to restrict freedom of these persons in the above-discussed way. So the Commission confirmed that while being in office Pocius and Valionis posed no threat to the interests of national security.

Having analyzed and evaluated the submitted documents, the Commission made a conclusion that at present some of the individuals included into the KGB reserve lists hold the positions of state politicians, judges or state officials. The Commission proposed that the Seimas should prepare and pass legal acts, regulating the order and conditions of publicizing individuals included in the KGB reserve ${ }^{108}$.

When the Seimas temporary Commission on the investigation of the activity of the KGB reserve confirmed the conclusion of the investigation and stated that the KGB reserve was a mobilization part of Soviet security and the fact that high officials of the country belonged to it did not pose a threat to national security, the Liberal and Center Union gave a critical estimation to these conclusions. According to the politicians, the Commission that investigated connections of high politicians with the KGB did not announce anything new and the conclusions it made were belated and did not, in essence, solve the ongoing KGB problem ${ }^{109}$. The Liberal Centrists were convinced that the previously proposed idea, to reform the temporary Commission on the investigation of the activity of KGB reservists and transform it into a permanent institution, should be reverted to. By the end of the term of the present Seimas, a newly formed and extended commission should complete the process of familiarization, investigation, and official announcement of all available information on Soviet repressive institutions and their personnel that operated in Lithuania. The Liberal Centrists claimed that only systemic, continual and comprehensive investigations of Soviet repressive institutions would make it possible to avoid the occasional witch hunt and finally bury the KGB ghost that had been wandering around the country for over a decade ${ }^{110}$.

\subsection{The Difference between the Public Opinion and the Position of the Political Elite}

The Social Research Institute conducted a survey of the attitudes of "ordinary people" - the senior generation of Lithuanian villages and small towns who lived during the Soviet period - towards the Soviet past. The majority of respondents were in favour of the "telling the truth" strategy - the past should

\footnotetext{
${ }^{108}$ The Commission confirmed the conclusion of the investigation results in the meeting of 1 March 2005. Voting results: "for" - 9, "against" - 1, "abstained" - 0 .

109 "Both Politicians and Clergymen Unraveling the KGB Reserve", Lietuvos rytas, 7 March 2005.

${ }^{110}$ Ibid.
} 
be identified and estimated from today's perspective. The major part of victims of the Soviet regime - former political prisoners and deportees -shared the same position. They would be satisfied, in their words, with a symbolically expressed implementation of "the truth" - identification and assessment and, preferably, a public apology from the responsible organizers and performers of the crimes of the communist regime. This group of people are particularly vulnerable to the spread of responsibility relativism within power institutions and official discourse. Some are hurt by the fact that "the former ones" have taken high positions without having honestly evaluated their collaboration with the Soviet regime.

Prior to the decision taken by the Seimas temporary Commission, the attitude of the Lithuanian population towards individuals who had been included in the KGB reserve was appraised. The majority of Lithuanian people held the opinion that those who in the Soviet period were included in the KGB reserve should not take high state posts. This was indicated by a sociological survey conducted by the Market Analysis and Research Group (MARG) at the request of the news agency BNS. Having been asked if individuals who in the past were in the KGB reserve had a moral right to hold high state posts, $63.3 \%$ of the respondents said they were against it, $28.6 \%$ believed they had such a moral right and $8.1 \%$ gave no answer to this question. A negative opinion about the fate of the former KGB reservists holding high posts was more often expressed by men $(66.1 \%)$, within age groups between $30-49$ and $70-74(68.5 \%)$, by respondents living in the centres of regions $(68.1 \%)$ or counties (67.2\%). More tolerant to the possibilities of the former reservists to be employed in state posts were young people of the age of $16-19(33.3 \%)$ and residents of major cities $(57.8 \%)$ as well as those earning over 600 Litas a month per family member. ${ }^{111}$

According to the "Sprinter Research" survey, ordered by DELFI and conducted 3-12 February 2005, 74 \% of the population of the country thought that it was important to publicize the names of people who had belonged to the KGB reserve, $13 \%$ expressed the opposite opinion, and $14 \%$ had no opinion on this issue. Senior people approved of publicizing the lists, while young people more often did not have a clear opinion on this matter. Respondents did not state a clear opinion on how high state officials included in KGB reserve lists should be treated (or how they themselves should behave). There were $27 \%$ who said that such people must unconditionally resign, the biggest group - $38 \%$ - thought that the possibility to further hold their positions should be related to the level of their collaboration with the KGB, $11 \%$ were of the opinion that merits of these people to Lithuania after the restoration of independence should be taken into account. The Lithuanian population does not approve of the restriction on the access to KGB archival documents. There were $80 \%$ of the respondents who gave a negative opinion on such actions of the authorities. Representatives of the senior generation showed strong disapproval of such restrictions, whereas younger respondents tended not to express their opinion ${ }^{112}$. It can be stated that

111 "The majority are against KGB Reservists to Hold High Posts", Lietuvos rytas, 18 February 2005.

112 "The majority of the country's population think that it is necessary to publicize the names of KGB reservists", www.delfi.lt, 21 February 2005. 
the prevalent public opinion did not correspond to the position of the highest state officials in appointing persons included in the KGB reserve to the positions important for national security, although features of dissociation from the solution of the problems of the past are also evident in the public opinion.

\section{Conclusions}

In the $80^{\prime}$ 's and $90^{\prime}$ s of the $20^{\text {th }}$ century, when the KGB was making preparations in advance to deal with tasks planned for "the special period" and was ready for urgent actions in peacetime extreme conditions, "the KGB reserve of reserve officers" was formed. This from which no more than 273 reserve officers were transferred from the armed forces reserve and were registered as KGB reserve officers. Selection to the KGB reserve, verification of reliability, extraction of an agreement to collaborate with the KGB and other repeated procedures of selection and reliability verification of a regular member of the KGB personnel was preformed. The verified loyalty of KGB reserve officers to the communist system and their suitability to implement KGB tasks could guarantee a faster way to get to the communist nomenclature or career advancement. Due to the negative attitudes towards the KGB prevailing among the majority of Lithuanian society, any kind of secret connections with this communist secret service were in advance regarded as capable of posing a threat to national security of Lithuania. Hence, a negative attitude of society towards relations with the KGB might have an impact on both the activity of the authorities of the Ministry of Foreign Affairs and the SSD. It could also pose as an indirect threat to national security as well as destabilize the political situation, or the situation in the institutions responsible for national security.

Regarding the legacy of the past, in the political circles of the country (due to relations of some of the representatives of the legislative and executive bodies with the former communist nomenclature, this due to the unimplemented deSovietization), unconstructive partial amnesia and relativism started to prevail. The discussion that followed added to a more distinctive manifestation of the attitude towards the past that hitherto existed in the highest political circles. The fact of being in the KGB reserve, as well as a possible existence of information in the hands of Russian special services, was not related to potential threats to national security. Reconsideration of the relationship to the KGB was turned towards parliamentary investigation and improvement of legal acts. Even though, from the formally legal point of view, in the publicized past of the high state officials-KGB reservists no traces of "conscious" collaboration were detected. But from the moral point of view, however, the involvement of one or another person's past in the activity of the KGB, an organization of repression and terror, for a greater part of society still remains hardly justifiable.

The need to deal with the past by identifying those who in the name of the former regime whom committed crimes, violated human rights, or had connections with the institutions that executed all this, is still felt among a certain part 
of society. The temporary Commission of the Seimas did not discover any threats to national security regarding the membership of high officials to the KGB reserve. However, this position differed from the public opinion expressed during sociological polls. This demonstrates that "a societal accord" on this issue has not yet been reached.

Vilnius, 13 September 2005 